\title{
Impression Management in Financial Reporting: Evidence on Management Commentary
}

\author{
Elzbieta JAWORSKA ${ }^{1}$ And Grzegorz BUCIOR ${ }^{2}$ \\ ${ }^{1}$ West Pomeranian University of Technology Szczecin, Faculty of Economics, Department of \\ Economics and Accounting, ul. Zolnierska, Szczecin, Poland \\ ${ }^{2}$ University of Gdansk, Faculty of Management, Department of Accounting, ul. Armii Krajowej \\ Sopot, Poland
}

Correspondence should be addressed to: Elzbieta JAWORSKA; ejaworska@zut.edu.pl

Received date: 12 November 2019; Accepted date:7 February 2020; Published date: 7 July 2020

Academic Editor: Sanja Broz Tominac

Copyright (C) 2020. Elzbieta JAWORSKA And Grzegorz BUCIOR. Distributed under Creative Commons Attribution 4.0 International CC-BY 4.0

\begin{abstract}
The purpose of this paper is to present issues of employing impression management strategies in business reports (management commentaries) for the sake of shaping the perception, opinions and decisions of stakeholders in the analyzed enterprises. The methods used to achieve the aim of the article involved: (a) analysis of the literature, (b) case study research. The paper focuses on the management commentary (business report), which is a source of financial and non-financial information about the company. Therefore, the characteristics of the management commentary and the impression management strategies were presented. The purpose of the empirical research was to answer the following research questions: (1) do the analyzed companies, that are required to prepare business reports, apply impression management strategies in the content of such reports? (2) do the criteria of assessment of the scope of impression management in the business report correspond with the list of strategies defined by the leading researchers, such as Merkl-Davies and Brennan? This paper makes a contribution to research on accounting narratives by indicating the possibility of extending the analytical database with management commentary, as an obligatory element of the annual report for the majority of the enterprises in accordance with the Accounting Act.
\end{abstract}

Keywords: Impression Management Strategies, Accounting Narratives, Disclosure of Information, Management Commentary

\section{Introduction}

Creating a good impression in one's field of activity is one of the ways of improving an enterprise's effectiveness in terms of market competition. This, in turn, enables companies to win over and maintain stakeholders' acceptance of their activities and operations. A positively perceived entity is better able to demonstrate a good image, which translates into a good reputation, making it easier to achieve

Cite this Article as: Elzbieta JAWORSKA And Grzegorz BUCIOR (2020)," Impression Management in Financial Reporting: Evidence on Management Commentary ", IBIMA Business Review, Vol. 2020 (2020), Article ID 693684, DOI: 10.5171/2020.693684 
better economic results in the future. Managers are therefore interested in building the desired image of enterprises. Studies presented in the literature show that companies apply diverse narratives to portray financial and non-financial information in their external reports in the most attractive way. Applying financial and non-financial reporting into building the desired company image enables the socalled "impression management" (Jones, 2011, Aerts, 1994 and Beattie, 2014).

In order to manage impressions in the reporting instruments, entities may manipulate both the manner in which reporting information is presented and the extent to which it is disclosed, using various strategies such as: rhetorical, thematic, readability, visual and structural manipulation, comparison and selection of results in presentation, or attribution, to name a few (Brennan et al., 2013, MerklDavies and Brennan, 2007, 2011, and Jaworska and Bucior 2017).

The purpose of this paper is to present issues of employing impression management strategies in business reports for the sake of shaping the opinions and decisions of stakeholders in the analyzed enterprises. This subject has been presented in theoretical terms, namely the review of the publications in question, and also empirical studies. An analysis of publications that present research results on using impression management was used to formulate the research questions: (1) do the analyzed companies, as the entities that draw up and disclose the business reports, apply impression management strategies in the content of such reports? (2) do the criteria of assessment of the scope of impression management in the business report correspond with the list of strategies defined by the leading researchers, such as Merkl-Davies and Brennan? Therefore, theoretical issues related to the management commentary as a source of financial and non-financial information about the enterprise and various impression management strategies, are discussed. The authors also examined the degree of employing particular impression management strategies in business reports with the application of the method described in the article, which also presents the results of the empirical research. In addition, in the authors' intention, the empirical context based on qualitative research according to the case study methodology is intended to serve the construction of criteria for further research in the field.

\section{Business Report as A Source of Financial and Non-Financial Information in An Enterprise}

A financial statement is the basic source of information in any enterprise. However, the financial data alone are not sufficient to fully assess the enterprise. Thus, the report needs additional information, not only quantitative and financial information, but also qualitative and non-financial, which are provided in the management commentary (business report). Not all enterprises need to prepare the management commentary, but only those to which Article 49 of the Accounting Act (The Accounting Act, 2019) applies, e.g. capital companies, limited joint-stock partnerships, cooperatives or state enterprises.

The management commentary, as a descriptive and numerical instrument, supplements the financial statement with information useful for understanding an enterprise's situation. The rules for the preparation of the management commentary are based on the following regulations:

1) The Accounting Act (The Accounting Act, 2019),

2) The Ordinance of the Minister of Finance on current and periodical information provided by the issuers of securities (The Ordinance, 2018),

3) Directive 2014/95/UE of the European Parliament and of the Council amending Directive 2013/34/UE as regards the disclosure of non-financial and diversity information by certain large undertakings and groups (Directive, 2014), which aims to enhance transparency, consistency and comparability of information concerning "Corporate Social Responsibility” (CSR),

The rules are also based on solutions provided by: 
1) National Accounting Standard no 9 (National Accounting Standard no $9,2014)$; and

2) A document published in 2010 by the International Accounting Standards Board (IASB) outlining its Practice Statement on the Management Board's Commentary (IFRS Practice Statement: Management Commentary. A framework for presentation) (IASB, 2010).

A management commentary should provide a context based on integrated information for stakeholders to interpret the financial situation and financial results of the enterprise (Kabalski, 2012).

A detailed scope of information presented in the management commentary is specified in Article 49-49b of the Accounting Act (The Accounting Act, 2019). Such a commentary should present relevant information about the assets and financial situation of the enterprise, including an assessment of the results, of risk factors and a description of hazards. In addition, being relevant for the assessment of the development, performance and position of the enterprise, the management commentary should also include at least the following key elements (The Accounting Act, 2019):

1) Financial efficiency ratios related to the operating activities of the enterprise,

2) Non-financial efficiency ratios related to the entity's performance as well as information on employees and environmental issues.

The corporate governance statement and non-financial statement (National Accounting Standard no 9, 2014) are an integral part of the management commentary. The obligation to include non-financial information in the management commentary in the form of the corporate governance statement is obligatory for the enterprises defined in Article 3 paragraph 1e points $1-6$ of the Accounting Act, including capital companies, limited joint-stock partnerships or certain general partnerships and limited partnerships, if, in the financial year for which they prepare their financial statements and in the preceding year, the following parameters have been exceeded (The Accounting Act, 2019):

1) 500 employees - for average annual full-time equivalent employment,

2) $85,000,000$ PLN - in case of the total of the balance sheet assets at the end of the financial year or $170,000,000$ PLN in the case of net revenues from the sale of products and goods for the financial year.

The non-financial information presented in the commentary should include a least (The Accounting Act, 2019): 1) a concise description of the business model of the enterprise, 2) key non-financial efficiency ratios related to the enterprise's activity, 3) a description of policies applied by the enterprise in relation to the following issues related to the CSR concept: social, employee, environmental, respect for human rights and counteracting corruption, as well as the results of applying these policies, 4) a description of due diligence procedures applied to these policies, and 5) a description of significant risks related to enterprises' business activities, which in turn may have an adverse impact on CSR-related issues. Consequently, one can note that expanding the management commentary with nonfinancial information related not only to the economic sphere, but also to the social and environmental ones, enables a better understanding and assessment of an enterprise's activity in terms of its impact on society and nature.

Polish literature studies concerning management commentaries focus primarily on the analysis and assessment of the scope of information disclosure by the companies listed in the Warsaw Stock Exchange, namely the following types of information:

1) General ones and related to financial statements (e.g. Gad, 2015), 
2) Environmental ones from enterprises of various industry sectors (e.g. Hońko, 2014 and Balicka, 2014),

3) Concerning diversity issues and policies in banks (e.g. Jaworska, 2016),

4) Concerning business model (e.g. Bek-Gaik and Rymkiewicz, 2017),

5) Concerning CSR implementation (e.g. Dyduch and Krasodomska, 2017).

It should be emphasized that the management commentary provides information on an entity from its management's perspective. It is a source of information about the enterprise's plans, its strategy, employed implementation methods, including also its development, as well as the anticipated financial standing, threats and risks, and the implementation of the CSR concept. The content and the manner of presenting information in the management commentary allow the management to create the image to gain stakeholders' acceptance of (legitimizing) the enterprise's performance within the impression management process. The management may therefore exploit the information about activity issues to manipulate stakeholders' perceptions.

This is indicated by studies that have adopted various sets of descriptive information included in annual reports as their analytical basis, e.g. in regard to: structural manipulation relating to the order in which information is processed in the commentary (Theis et al. 2012), or the influence of quantification on information processing by non-professional investors in narrative disclosures (Bauch, 2019). The vast majority of the studies focus on impression management in letters to shareholders, while there is a deficit of literature and studies analyzing impression management application in business reports. It's the authors' intention to fill this research gap; hence this article is the first step in that direction.

\section{Impression Management Strategies in Enterprise Narratives}

A company is expected to bear the responsibility for its environmental impact. As a result, its stakeholders put pressure on a business entity expecting it to substantiate its activities and assert compliance with various standards and rules as well as social values. The need for stakeholders' acceptance entails the necessity to undertake actual steps or feigning that such steps have been taken.

The impression management of an enterprise can thus be defined as the process of creating and maintaining an enterprise's image as perceived by its stakeholders, which allows a business entity to benefit from this image in the future.

Such impressions can be created by the information presented in an entity's external reports. The process demands that the management selects the proper information to be disclosed as well as presents them so that they influence the readers' judgement and their decisions in the way expected by the enterprise (Cho et al., 2015, and Jaworska and Bucior, 2017).

The objectives of impression management in the management commentary include (Aerts, 2005, and Baird and Zelin 2000):

1) Enhancing the image and reputation of the enterprise (presenting an entity in a better light than in reality),

2) Sustaining the sense of credibility among the entity's stakeholders and increasing confidence in the enterprise,

3) Improving its relations with the stakeholders. This results from the intention to create a good impression, to prevent a bad impression, or to conceal information that can provoke a bad impression about the entity (Jaworska, Bucior 2017).

The expected impression is accomplished by applying various strategies (Brenan and Merkle-Davies, 2013, Merkl-Davies and Brenan 2007, 2011, Brennan et al., 2009, and Jaworska and Bucior, 2017):

1) Rhetorical manipulation,

2) Thematic manipulation,

3) Reading ease manipulation,

4) Visual and structural manipulation,

5) Performance comparison, 
6) Selectivity of results in presentation,

7) Attribution of performance.

The rhetorical manipulation strategy involves employing language phrases, which are a characteristic of beneficial rhetoric in the reports presenting the entity's results (Brennan and Merkl-Davies, 2013; Brennan et al., 2009; and MerklDavies and Brennan 2007). This strategy is used to prevent bad impressions. In this case, the instrument of manipulation is the semantic category of conviction that determines the meaning of the content (Aerts and Yan, 2017, and Fijałkowska et al. 2015).

The thematic manipulation strategy focuses on the content and tone of the information or announcements (MerklDavies and Brenan, 2007, Brenan et al., 2009, and Brennan and Merkl-Davies, 2013). The purpose of manipulating stakeholders' perceptions is to emphasize good news and to understate bad news in reports, drawing the readers' attention to positive and negative keywords (Clatworthy and Jones, 2003).

Modification of the readability of management commentary is related to the issue of reading ease manipulation (MerklDavies and Brenan, 2007, 2011, Brenan et al., 2009, and Brennan and Merkl-Davies, 2013).

Readability reflects the ability of the report's recipient to decode the intended message (Loughran and McDonald, 2016). The readability level relies on the language difficulty reflected in the choice of vocabulary and the length of sentences in the reports. It is assumed that the longer the sentences, the lower the readability of the management commentary. Another aspect affecting the readability score is the use of jargon. It may have a negative impact on the comprehension of the content if the recipient of the commentary lacks adequate knowledge (Loughran and McDonald, 2014). Managers obfuscate the image of the entity mainly in the case of poor results.
The readability level is measured with various traditional formulas, such as Flesch index or Fog index (Li, 2008, Bloomfield, 2008 and Guay et al. 2015) or FleschKincaid (De Franco et al. 2015), or by specifying the number of words in the annual report (Li, 2008).

The strategy of visual and structural manipulation may be used to emphasize a certain content of the management commentary. It involves attracting the attention of recipients of reports to good news and diverting their attention from bad news (Merkl-Davies and Brenan, 2007, 2011, Brenan et al., 2009, and Brennan and Merkl-Davies, 2013). The results are reached by positioning the information in the text, namely by placing good news in the first part of the report and bad news in the middle of the text (Baird and Zelin, 2000, and Theis et al. 2012), according to Hoghart and Einhort's belief-adjustment model (1992). Furthermore, good news is highlighted by means of graphical elements, font style, font size, color or underlining (Hellmann et al., 2017, Jones, 2011, Hirshleifer and Teoh, 2003; Courtis, 2004, Merkl-Davies and Brennan, 2007, and Jaworska and Bucior, 2017). Entities may also repeat certain information in the commentary in order to facilitate the understanding of the information presented, but on the other hand it can result in information overload and distraction of the readers' attention (MerklDavies and Brennan 2007).

Stakeholders' perception can be manipulated by applying a performance comparison strategy. This strategy involves focusing on selected benchmarks, which show the performance of the enterprise in the most favorable light (Merkl-Davies and Brenan, 2007, 2011, Brenan et al., 2009, and Brennan and Merkl-Davies, 2013). One of the techniques is comparing themselves with worse enterprises.

The strategy of result selectivity assumes the selection from various information concerning the enterprises' financial results, of only those parts that enable the presentation of the entity in the most favorable light (Merkl-Davies and Brenan, 
2007, 2011, Brenan et al., 2009, and Brennan and Merkl-Davies, 2013).

Within the framework of impression management in external reports, the enterprise may also apply internal and external attribution, imposing an interpretation of the causes of events (Clatworthy and Jones, 2003, Barton and Mercer, 2005, Hooghiemstra, 2008, Aerts, 1994, 2005, Aerts and Yan, 2017, and Yang and Liu, 2017). It assumes the attribution of positive results to the enterprise and negative results to external factors that are independent from the entity.

The enterprise uses an internal attribution for the sake of maintaining a good image. It will therefore attribute a positive outcome to internal factors (e.g. knowledge and skills of its employees or their efforts), providing a favorable interpretation of the results, i.e. highlighting its own responsibility for good results (Libby and Rennekamp, 2012, and Keusch et al. 2012). External attribution is used for the sake of minimalizing the effects of events threatening the loss of a positive impression. In the case of external attribution, the blame for the enterprise's negative results is assigned to external factors (e.g., economic situation - crisis on the market, other enterprises, legal regulations, etc.) (Koo and Yang, 2018, and Meier, 2012).

\section{Impression Management in The Business Report - Empirical Study}

The source of information that can be used to build the image and reputation of the company is, among others, the business report. Therefore, it is important to study the possibility for enterprises to apply impression management strategies to shape this image.

\section{Research Questions}

The purpose of the empirical research was to answer the following research questions:

RQ1: Do the analyzed companies, as the entities that draw up and disclose the business report, apply impression management strategies in the content of such reports?

RQ2: Do the criteria of assessment of the scope of impression management in the business report correspond with the list of strategies defined by the leading researchers, such as Merkl-Davies and Brennan?

\section{Selection of cases}

The research method applied in this article is a three-fold case study, which the authors chose with the following considerations:

1) The access to the authors of the reports of the reporting entity which enabled the possibility of conducting interviews,

2) The intention to analyze enterprises of different sizes: small, medium and large,

3) An adequate level of the management commentaries, especially in reference to structural completeness and relevant correctness,

4) Excluding the affiliation of enterprises to a group of public companies - this was due to the authors' intention to verify whether companies not required to make their results public, such as listed companies, apply impression management strategies or not.

As a consequence, the study has analyzed the three companies of three different categories:

1) Small entities pursuant to the Accounting Act (showing at least two out of three parameters: PLN $25,500,000$ - for the sum of assets in the balance sheet at the end of the financial year; PLN 51,000,000 for the net revenues from the sale of products and goods for the financial year; and 50 persons - for the average annual employment in fulltime equivalents) (The Accounting Act, 2019),

2) Medium-sized entities pursuant to the act Entrepreneurs Act (average annual employment of less than 250 employees and annual net turnover from the sale of goods, products, services and financial operations not exceeding the PLN equivalent of EUR 50 million, or the sum of assets of the balance sheet as of the end of one of these years, not exceeding the PLN 
equivalent of EUR 43 million) (The Entrepreneurs Act, 2018),

3) Large entities - the entities exceeding the parameters specified in the above points 1 and 2 .

The two different standards concerning the size of the company are related to the possibility of not submitting the report on activities pursuant to the provision of Article 49(4) of the Accounting Act (The Accounting Act, 2019). According to the regulations, small entities are not obliged to draw up the management commentary, provided that certain information is included in the notes to the balance sheet. Thus, while selecting an entity from the group of small enterprises, it had to be determined whether the entity did not benefit from the regulation that allows to abandon the preparation of the management commentary. The content that, in such a case, is included in the introduction of the balance sheet, or in the notes of the financial statement is insufficient to serve as a source of a meaningful analysis.

\section{Selection of Data for the Analysis}

According to Yin (2015), source documents, archive records, interviews, direct and participatory observations or physical artifacts constitute the most common evidence sources in the case studies. The following elements were adopted in this study:

1) A free interview with the individuals responsible for the management commentaries preparation,

2) Structured interviews (questionnaire supported) with the same individuals,

3) The management commentaries published in the Ministry of Finance repository.

The cases have been assessed against the criteria, following the steps:

1) an interview with the individuals responsible for the financial statement draw-up
1K1 technical and organizational issues in the process of drawing up the management commentary; $1 \mathrm{~K} 2$ the management commentary author's awareness of impression management strategies usage;

$1 \mathrm{~K} 3$ the influence of supervisors / decision-makers on the content of the management commentary - in case the person(s) writing the report is/are not the person(s) responsible for the reporting;

2) questionnaire completed by the person drawing up the management commentary

2K1 technical and organizational issues in the process of drawing up the management commentary; $2 \mathrm{~K} 2$ the management commentary author's awareness of impression management strategies usage;

2K3 the influence of supervisors/decision-makers on the content of the management commentary - as described above;

3) management commentary analysis $3 \mathrm{~K} 1$ formal and structural size of the report;

$3 \mathrm{~K} 2$ factual structure of the report; 3K3 employment of impression management strategies:

3K3A: rhetorical manipulation, 3K3B: thematic manipulation, 3K3C: reading ease manipulation, 3K3D: visual and structural manipulation,

3K3E: performance comparison, 3K3F: selectivity of results presentation,

3K3G: attribution.

The duplication of the majority of the information obtained from the free and structured interviews was aimed at verifying potential errors that could result from the specificity of the techniques used. The researchers indicate that the results obtained when applying a structured and written form of the questionnaire, frequently provide different results than those obtained during an interview, especially if the interview focuses on a definite and narrow subject matter (Hawkins, 2018, and Campbell et al. 2013). This type of error was also observed in this 
study - the conclusions from the analysis of $1 \mathrm{~K} 2$ and $2 \mathrm{~K} 2$ criteria are one of the examples.

The key analysis has pertained to the enterprises' management commentaries. The reports have been processed and the content that could potentially contain elements of impression management was extracted from the documents. As the original format of the reports precluded the calculation of the statistical values (the number of sentences, words and characters), which is critical for the sake of reading ease strategy verification, the reports were next converted into editable formats. The analysis of reports that were carried out against the group 3 criteria, was intended to answer the research questions. The criteria of group 1 and 2 were of auxiliary importance and did not directly serve the purpose of this paper. However, they indicated the direction for further research in the subject matter to the authors.

\section{Results}

\section{Case no 1}

The first case - a limited liability company employing 38 employees. The company operates in the textile industry and its main business activity is the production and sale of duvets and pillows. The company keeps its books and records independently, and the person responsible for the company's reporting is the chief accountant.

Stages /criteria:

- 1K1: the management commentary is drawn up by the chief accountant without the participation of the management board members, using universal computer-based office tools (MS Office),

- 1K2: not found.

- 1K3: the management board members either do not interfere or interfere at a minimal level.

- 2K1: convergent with $1 \mathrm{~K} 1$.

- 2K2: the company's CEO is aware of the impression management strategies

- 2K3: convergent with $1 \mathrm{~K} 3$.

- 3K1: 2017 management commentary consisted of 12 pages divided into 10 chapters; the text consisted of 260 sentences, 3,205 words and 19,250 characters.

- 3K2: the structure of the report complies with the minimum standard specified in the Accounting Act.

- 3K3A: not found,

- 3K3B: not found,

- 3K3C: not found,

- 3K3D: structural manipulation reported,

- 3K3E: not found,

- 3K3F: not found,

- 3K3G: external and internal attribution reported.

\section{Case no 2}

The second case - a limited liability company employing 128 employees, operating in the telecommunication industry. The company provides services related to the construction and maintenance of the telecommunication infrastructure. The books and records are kept in an external accounting office; the employee of the accounting office is the author of the interim reports.

\section{Stages/criteria:}

- 1K1: the management commentary is drawn up in cooperation with the staff of the accounting department. The final content to be submitted to the management board is drawn up by the chief accountant. The report is prepared using MS Office.

- 1K2: not found.

- 1K3: the member of the management responsible for the financial matters has an impact on the final form of the report.

- $2 \mathrm{~K} 1$ : convergent with $1 \mathrm{~K} 1$.

- 2K2: convergent with $1 \mathrm{~K} 2$.

- 2K3: convergent with $1 \mathrm{~K} 3$.

- 3K1: 2017 management commentary consisted of 29 pages divided into 29 chapters; the text consisted of 98 sentences 10,023 words and 82,406 characters.

- 3K2: the report contains both, the mandatory chapters and the additional ones

- 3K3A: limited degree,

- 3K3B: not found, 
- 3K3C: average degree,

- 3K3D: structural manipulation reported,

- 3K3E: limited degree,

- 3K3F: average degree,

- 3K3G: external an internal attribution reported.

\section{Case no 3}

The third case - a public limited company providing services to the seaport's operation. The company employs 280 employees. The company's accounting books are kept by the employees and the chief accountant is responsible for the company's reporting operations.

Stages/criteria:

- 1K1: the management commentary is drawn up by the chief accountant with the support of the designated staff of the accounting department. The reports are produced with dedicated computer applications.

- 1K2: the awareness of the application of the impression management strategy among the chief accountant and the member of the management board who is responsible for the financial reporting.

- 1K3: the member of the management has an impact on the content of several elements of the management commentary.

- $2 \mathrm{~K} 1$ : convergent with $1 \mathrm{~K} 1$.

- 2K2: convergent with $1 \mathrm{~K} 2$.

- 2K3: convergent with 1K3, a stronger emphasis on the potential influence of the management board member on the content of the report.

- 3K1: the report for 2017 consisted of 104 pages and 7 chapters; the text consisted of 398 sentences, 31,808 words and 251,412 characters.

- 3K2: significantly expanded structure in relation to the statutory minimum.

- 3K3A: average degree,

- 3K3B: average degree,

- 3K3C: limited degree,

- 3K3D: structural manipulation reported,

- 3K3E: limited degree,
- 3K3F: average degree,

- 3K3G: external an internal attribution reported.

\section{Discussion}

The presented results indicate that the impression management strategies were traced in all examined management commentaries - thus, PB1 was positively verified, whereby the scope and level of the techniques and methods used to manage the impression management were different in each case. The size of the company seems to be the main determinant of this scenario - the highest saturation with the techniques and methods of impression management occurred in the management commentary of the largest entity, while it was significantly lower in the case of the medium entity and definitely the lowest in the case of the smallest one. The type of the study as well as the way in which the study was conducted did not allow the identification of other factors that could potentially affect the scope and degree of impression management in the business report, therefore, in order to identify those aspects, a deeper quantitative and qualitative survey is necessary.

The relatively strong presence of an internal and external attribution noticed in the small entity's management commentary, appears intriguing and inspires for further research. This situation may result from the fact, that since 2017 (the period under analysis), the entities have been obliged to send the reports to the repository of the Ministry of Justice in the electronic form. The repository is an open database with an unrestricted access, and the submitted reports are available for all interested parties. The awareness of the accessibility of such reports may increase the tendency to the exploitation of impression management. This, however, will demand more extended studies involving the issue of the time horizon.

The answer to PB2 has proved to be more complex. The analysis shows that the set of the applied strategies is related to the size of the entity. This may suggest the construction of various categories for the assessment of the management 
commentary of different groups of enterprises. Also, other potentially influential factors (industry, financial condition, ownership structure, etc.) should be examined with respect to this context.

\section{Conclusions}

The study under evaluation confirmed that the selected enterprises employ the impression management strategies in their external reporting. The results are not surprising and confirm the studies conducted so far [np. Hadro et al., 2017, and Jaworska and Bucior, 2018]. So far, the researchers have focused on the analysis of letters from management to shareholders. Such letters are written primarily by public limited companies, mostly by the ones that, either offer their instruments in the financial markets, or direct their products to a wide range of customers. This is a minority among the companies that disclose their annual reports. Thus, the study contributes to the development of the research trend that explores the narrative of the reports by indicating the potential of extending the analytical database with the management commentary, which is an obligatory element of the annual report for the majority of enterprises subject to the regime of the Accounting Act. The method applied in the study, namely the transformation of the management commentary and its subsequent analysis in terms of the impression management strategies in the content, constitutes a starting point for further quantitative and qualitative research in the relevant subject matter. This would enable the formulation of significant general conclusions in terms of the economic turnover subject, namely the manipulation with the disclosures. In relation to this article, the lack of such a possibility is the main limitation in the presented study, because, as in any study based on case study methodology, the accumulated conclusions cannot be extended to full or at least wider set of enterprises. Other limitations to this study include:

- The possibility of extracting an incorrect abstract from the management commentary, and subsequently analysing this abstract,
- Potential mistakes in the analysis of the content of the reports made by the authors,

- The possibility of acquiring erroneous information coming from the interview or the questionnaire.

In the authors' opinion, the results of this research demonstrate both the possibility and the rationale for further studies in this area.

\section{References}

- $\quad$ Aerts, W. (1994), 'Accounting logic as an explanatory category in narrative accounting disclosures,' Accounting, Organizations and Society 19 (4-5), 337-353.

- Aerts, W. (2005), 'Picking up the pieces: impression management in the retrospective attributional framing of accounting outcomes,' Accounting, Organizations and Society 30 (6), 493517.

- Aerts, W. and Yan, B. (2017), 'Rhetorical impression management in the letter to shareholders and institutional setting: A metadiscourse perspective,' Accounting, Auditing \& Accountability Journal 30 (2), 404-432.

- Baird, JE. and Zelin, RC. (2000), 'The effects of information ordering on investor perceptions: An experiment utilizing presidents' letters,' Journal of Financial and Strategic Decisions 13 (3), 71-81.

- Balicka, A. (2014), 'Informacje środowiskowe $\mathrm{w}$ raportach rocznych przedsiębiorstw branży motoryzacyjnej,' Finanse, Rynki Finansowe, Ubezpieczenia 827 (69), 137-145.

- Barton, J. and Mercer, M. (2005), 'To blame or not to blame: analysts' reactions to explanations of poor management performance,' Journal of Accounting and Economics 39, 509533.

- Bauch, KA. (2019), 'Quantification in Narrative Disclosures: Effects on NonProfessional Investors' Information Processing under Time Pressure,' SSRN (February 20, 2019). [Online], [Retrieved March 1, 2019]. Available: http://dx.doi.org/10.2139/ssrn.32935 $\underline{49}$.

- Beattie, V. (2014), 'Accounting narratives and the narrative turn in 
accounting research: Issues, theory, methodology, methods and a research framework,' The British Accounting Review 46, 111-134.

- Bek-Gaik, B. and Rymkiewicz, B. (2017), 'Model biznesu w sprawozdawczości organizacji - ocena ujawnień w sprawozdaniu z działalności,' Finanse, Rynki Finansowe, Ubezpieczenia 1 (85), 201-214.

- Bloomfield, R. (2008), 'Discussion of Annual Report Readability, Current Earnings, and Earnings Persistence,' Journal of Accounting and Economics 45, 248-252.

- Brenan, N., Guillamon-Saorin, E. and Pierce, A. (2009), 'Impression management: Developing and illustrating a scheme of analysis for narrative disclosures - A methodological note,' Accounting, Auditing and Accountability Journal 22 (5), 789-832.

- Brennan, NM. and Merkl-Davies, DM. (2013), Accounting Narratives and Impression Management, The Routledge Companion to Communication in Accounting, Jack, L, Davison, J, and Craig, R. (eds), London: Routledge, 109-132.

- Campbell, JL., Quincy, C., Osserman, J. and Pedesen, OK. (2013), 'Coding indepth semistructured interviews: Problems of unitization and intercoder reliability and agreement,' Sociological Methods \& Research 42 (3), 294-320.

- Cho, CH., Laine, M., Roberts, RW. and Rodrigue, M. (2015), 'Organized hypocrisy, organizational façades, and sustainability reporting,' Accounting, Organizations and Society 40, 78-94.

- Clatworthy, M. and Jones, MJ. (2003), 'Financial reporting of good news and bad news: evidence from accounting narratives,' Accounting and Business Research 33 (3), 171-185.

- Courtis, JK. (2004), 'Colour as visual rhetoric in financial reporting,' Accounting Forum 28 (3), 265-281.

- De Franco, G., Hope, O., Vyas, D. and Zhou, Y. (2015), 'Analyst Report Readability,' Contemporary Accounting Research 32, 76-104.

- Directive 2014/95/EU of the European Parliament and of the Council of 22
October $2014 \quad$ amending Directive 2013/34/EU as regards disclosure of non-financial and diversity information by certain large undertakings and groups, (OJ L 330, 15.11.2014).

- Dyduch, J. and Krasodomska, J. (2017), 'Determinants of corporate social responsibility disclosure: An empirical study of Polish listed companies,' Sustainability 9 (11), 1934 (p. 1-24).

- Fijałkowska, D., Klimczak, KM. and Pauka, M. (2015), 'Nadmierny optymizm w listach do akcjonariuszy wybranych spółek GPW w Warszawie,' Finanse, Rynki Finansowe, Ubezpieczenia 855 (74), t. 1, 35-45.

- Gad, J. (2015), 'Sprawozdanie z działalności we współczesnym modelu raportowania - praktyka sprawozdawcza spółek publicznych notowanych na GPW,' Zarzadzanie i Finanse 1, 79-90.

- Guay, W., Samuels, D. and Taylor, D. (2016), 'Guiding Through the Fog: Financial Statement Complexity and Voluntary Disclosure,' Journal of Accounting and Economics 62 (2-3), November-December, 234-269.

- Hadro, D., Klimczak, KM. and Pauka, M. (2017), 'Impression Management in Letters to Shareholders: Evidence from Poland,' Accounting in Europe 14(3), 305-330.

- Hawkins, JE. (2018), 'The Practical Utility and Suitability of Email Interviews in Qualitative Research,' The Qualitative Report 23 (2), 493-501.

- Hellmann, A., Yeow, Ch. and De Mello, L. (2017), 'The influence of textual presentation order and graphical presentation on the judgements of non-professional investors,' Accounting and Business Research 47 (4), 455-470.

- Hirshleifer, D. and Teoh, S. (2003), 'Limited attention, information disclosure and financial reporting,' Journal of Accounting Economics 36 (13), 337-386.

- Hogarth, RM. and Einhorn, HJ. (1992), 'Order effects in belief updating: The belief-adjustment model,' Cognitive Psychology 24, 1-55.

- Hońko, S. (2014), 'Sprawozdanie z działalności jako źródło informacji o 
oddziaływaniu jednostki na środowisko,' Ekonomia i Środowisko 3 (50), 144-155.

- Hooghiemstra, R. (2008), 'East West differences in attributions for company performance: a content analysis of Japanese and US corporate annual reports,' Journal of CrossCultural Psychology 39, 618-629.

- $\quad$ IASB (2010), IFRS Practice Statement. Management Commentary. A Framework for Presentation. [Online] [Retrieved April 15, 2019]. Available: https://service.betterregulation.com/s ites/default/files/upload/201903/ifrspracticestatement11130.pdf.

- Jaworska, E. (2016), 'Diversity management and reporting in selected companies', Prace Naukowe Uniwersytetu Ekonomicznego we Wrocławiu 434, 48-62.

- Jaworska, E. and Bucior, G. (2017), 'Self-presentation. Enterprise impression management as part of external reporting,' Prace Naukowe Uniwersytetu Ekonomicznego we Wrocławiu 474, 150-159.

- Jaworska, E. and Bucior, G. (2018), 'Atrybucja jako strategia zarządzania wrażeniem w raportowaniu zewnętrznym - przykład spółki z większościowym udziałem Skarbu Państwa,' Prace Naukowe Uniwersytetu Ekonomicznego we Wrocławiu 514, 128-138.

- Jones, MJ. (2011), 'The nature, use and impression management of graphs in social and environmental accounting,' Accounting Forum 35, 75-89.

- Kabalski, P. (2012), 'The IASB's Management Commentary and Modern Paradigms of Management,' International Journal of Business and Management 7 (6), March, 90-98.

- Keusch, T., Bollen, LHH. and Hassink, HLH. (2012), 'Self-serving Bias in Annual Report Narratives: An Empirical Analysis of the Impact of Economic Crises,' European Accounting Review 21 (3), 623-648.

- Koo, J. and Yang, D. (2018), 'Managerial Overconfidence, Self-Attribution Bias, and Downwardly Sticky Investment: Evidence from Korea,' Emerging Markets Finance \& Trade 54 (1), 144161.

- Li, F. (2008), 'Annual Report Readability, Current Earnings, and
Earnings Persistence,' Journal of Accounting and Economics 45, 221-47.

- Libby, R. and Rennekamp, K. (2012), 'Self-Serving Attribution Bias, Overconfidence, and the Issuance of Management Forecasts,' Journal of Accounting Research 50 (1), 197-231.

- Loughran, T. and Mcdonald, B. (2014), 'Measuring Readability in Financial Disclosures,' Journal of Finance 69, 1643-1671.

- Loughran, T. and McDonald, B. (2016), 'Textual Analysis in Accounting and Finance: A Survey,' Journal of Accounting Research 54 (4), September, 1187-1230.

- Meier, F. (2012), Determinants and consequences of attribution statements on corporate financial performance outcomes in the annual report: an empirical analysis of UK listed firms, University of Bradford, Bradford.

- Merkl-Davies, DM. and Brennan, NM. (2007), 'Discretionary disclosure strategies in corporate narratives: incremental information or impression management?' Journal of Accounting Literature 26, 116-194.

- Merkl-Davies, DM. and Brennan, NM. (2011), 'A conceptual framework of impression management: new insights from psychology, sociology, and critical perspectives,' Accounting and Business Research 41 (5), 415-437.

- National Accounting Standard no 9 „Management commentary" [Krajowy Standard Rachunkowości nr 9 'Sprawozdanie z działalności'], Dz.Urz. MRiF z 2018 r. poz. 4.

- The Accounting Act of September 29, 1994 [Ustawa z dnia 29 września 1994 r. o rachunkowości], Dz.U. z 2019 r., poz. 351.

- The Entrepreneurs Act of March 6, 2018 [Ustawa z dnia 6 marca 2018 r. Prawo przedsiębiorców], Dz.U. z 2018 r. poz. 646.

- The Ordinance of the Minister of Finance of March 29, 2018 regarding current and periodic information published by issuers of securities and conditions for recognizing information required by the law of a non-member country as equivalent, Dz.U. z 2018 r. poz. 757.

- Theis, JCh., Yankova, K. and Eulerich, M. (2012), 'Information order effects in the context of management 
commentary - initial experimental evidence,' Journal of Management Control November 23 (2), 133-150.

- Yang, JH. and Liu, S. (2017), 'Accounting narratives and impression management on social media,'
Accounting and Business Research 47 (6), 673-694.

- Yin, RK. (2015), Studium przypadku w badaniach naukowych. Projektowanie i metody, Wydawnictwo Uniwersytetu Jagiellońskiego, Kraków. 